25. Лозинська I. Правовий закон і стандарти правотворчості правової держави URL: http://vuzlib.com/content/view/2419/112.

26. Козюбра М. Принципи права: методологічні підходи до розуміння природи та класифікації в умовах сучасних глобалізаційних трансформацій. Право України. 2017. № 11. C. $142-164$.

\title{
THE RELATION OF NATURAL AND POSITIVE LAW IN THE CREATIVITY OF M. KOZACHINSKY
}

\author{
Mariya Bratasyuk \\ Lviv National University by Ivan Franko \\ Universytetska str., 1, 79000, Lviv, Ukraine \\ e-mail:Pateu_mag@ukr.net
}

The article covers the philosophical and legal views of the professor of Kyiv-Mohyla Academy M. Kozachynsky. It has been shown that in the conditions of Russia's subjugation of Ukraine, the displacement of natural and moral regulators of life on Ukrainian lands developed a natural legal paradigm. M. Kozachinsky substantiated the idea of the primacy and definiteness of natural law with respect to law as secondary and derived from it, and developed substantive-legal criteria of law as a state-power phenomenon.

M. Kozachinsky developed his natural-law views in a troubling time for Ukraine, when the Russian Empire destroyed the Cossack state, destroyed ZaporizhzhyaSich, enslaved the Ukrainians, divided the territory into provinces, introduced the Russian system of administrative management. The occupation of Ukraine, which began in the time of Alexei Mikhailovich, actually took place. With these changes, the Ukrainian legal system was destroyed, the Ukrainian natural-legal tradition, characterized by democracy and moral and ethical dimensions, the weight of which has remained since the days of princely Ukraine, has waned. In that Russian Empire dominated legal doctrine and its ideology and practice. The law that embodied the will of the sovereign, the supreme power was the main and almost the only source of law. The Russian legal system is characterized by despotism and tyranny.

The basis for the development of natural-law ideas of M. Kozachinsky was a new image of a man, formed by the thinkers of early Ukrainian humanism. It is first of all about the recognition of human dignity, which is inalienable from his individual freedom and knowledge.

The natural right for this thinker is a set of principles whose origins in the nature of being and God are true, that is, they are of superstitious origin and are integral to the fundamental foundations of being, reflecting its fundamental connections and values. The origins of natural law also in human existence, in the human conscience - this interpretation fills the natural law with moral content. Such a symbiosis of law and morality, which was typical of the Ukrainian legal tradition of the time, suggests that Ukraine then created and developed both theoretically and practically legal morality, which is organically inherent in the natural-legal paradigm, in contrast to the legalistic one, where the right is conceived as a purely political power, devoid of moral dimension.

The philosophy of law of M. Kozachinsky gives an opportunity to see how radically different national legal paradigms of the development of Ukraine and imperial Russia of the XVIII century.

Key words: natural law, principles of law, legal custom, common law, law, human rights, humanism, legal tradition, legal law, non-legal law, natural law doctrine. 


\author{
УДК 116.37:001.8:005 \\ DOI https://doi.org/10.30970/2078-6999-2019-23-16
}

\title{
ФЕНОМЕН ПОЗААКАДЕМІЧНОЇ ОСВІТИ В СУЧАСНОМУ СУСПІЛЬСТВІ
}

\author{
Галина Жукова \\ Національний педагогічний університет імені М.П. Драгоманова \\ вул. Тургенівська, 8/14, 02000, м. Київ, Україна \\ e-mail: galinazh1299@gmail.com
}

Розгляд безперервної освіти як соціального інституту зумовлює актуальність інтеграційного підходу, який передбачає використання комплексу заходів щодо міждисциплінарності сучасного наукового знання. Актуальність пошуку нових контекстів освіти як продуктивного напряму розвитку наукових досліджень окреслює позаакадемічну освіту як діяльнісну парадигму, яка потребує теоретичного аналізу та наукового обгрунтування. Діалектика навчання і виховання існує в освіті як суперечність культури і цивілізації всередині соціуму, що відкрито виражається в суперечностях навчання і виховання. Найбільше нівелюється цей процес в освіті, коли він поглинається або зливається з навчанням навичок і вмінь відповідної професії. У культурологічному вимірі освіти у кризові періоди також відбувається перекіс взаємодії навчання і виховання. Виховання тут повинно виражатися в державній політиці вибудовування змісту освіти, у якому мають бути представлені досягнення світової і національної культур. Становлення позаакадемічної освіти розглядається як соціокультурний феномен, що відображає зростаючу потребу особистості в отриманні різноманітних освітніх послуг. Ця освітня система має такі ознаки, як: організованість, систематичність, професійна спрямованість, безперервність, актуальність щодо вже наявних знань, отриманих особистістю за межами академічної освітньої системи. Основними принципами позаакадемічної освіти, відповідно до досліджень вітчизняних і закордонних учених та українських державних програм, є: орієнтація навчання на задоволення актуальних потреб його суб'єктів; зв'язок із практикою, який проявляється у спрямованості на здобуття життєвих навичок і підготовку до активної участі в житті суспільства; наявність мобільних гнучких програм, індивідуальних освітніх стратегій, спрямованих на вираження, прийняття і повагу індивідуальних особливостей.

Ключові слова: безперервна освіта, професійна освіта, позаакадемічна освіта, система освіти.

Тотальне заповнення освітнього простору академічною освітою, що багатократно імітує і поширює власні продуковані афронти, не може не привести до осмислення проблем українських об'єктивних закономірностей сучасних глобалізаційних процесів. Специфіка організації життя людини, щоденне освітнє включення в потоки комунікативних моделей і стереотипів зумовлюють формування етнонаціональної свідомості, державного патріотизму, національної гідності й самоповаги. Зміст і засоби позаакадемічної освіти, яка заповнює нішу, що не увібрала в себе академічна освіта, у нових історичних умовах можуть надати індивідові безліч можливостей для включення в політичне й економічне життя, стати чинником формування нової української особистості, яка є свідомим творцем своєї держави. Освіта нині долучає людину до безлічі потенцій для включення в різного роду системи, що формуються за певними правилами широких можливостей для новацій, використання міжпредметних зв'язків, дозволяють творчо підходити до моделювання структури своєї професійної роботи, обирати різноманітні нестандартні особистісно орієнтовані пізнавально-виховні спрямування.

(C) Г. Жукова, 2019 
Освітній процес завжди налаштований на дослідницьку роботу для вдосконалення духовного і навчального ресурсу людини. У відродженні та затвердженні демократичних і суспільно-інформаційних засад, їх взаємозв'язку з концептуально-маркетинговою стратегією науки полягає культуротворча функція позаакадемічної освіти. Тобто позаакадемічна освіта $є$ проекцією нової концепції навчання, векторами якої $є$ випереджальна роль навчання, проективна інтелектуальна автономія, філософська рефлексія, теоретична самостійна підготовка учнів, постановка і перевірка гіпотез. Декларована діяльність закладів позаакадемічної освіти є цільовим і інструментальним взірцем акумуляції наявних знань, актуалізації накопичених компетенцій, виявлення дефіциту та верифікацією знань.

Актуальність дослідження. Функціонування і розвиток системи освіти як соціально-філософського інституту характеризується специфічними внутрішніми суперечностіми, які відображаються в науковому пізнанні безлічі теоретичних проблем. 3 усієі сукупності проблем поряд із педагогічними та психологічними можна виділити філософські, які відображають суперечливі взаємодії системи освіти із суспільством як глобально-соціальною системою. Взаємозв'язок системи освіти із суспільством виражається у структурі їх взаємодії, що становить провідний напрям філософських проблем освіти.

Аналіз останніх досліджень і публікацій. Широке коло формування проблем освітньої системи з огляду на іiі багатоаспектний характер базується на різних теоретичних підходах. Зокрема, аспекти даної проблеми знаходимо у працях В. Волковського [1], який розглянув ідею суспільності в Україні, зазначивши важливість досліджень позаакадемічної освіти, на які він спирався. Цінним для нашого дослідження $є$ те, що він провів філософську лінію від публіцистичної діяльності початку XIX ст. до сучасних інтернет-проєктів. У філософській системі позаакадемічної освіти вчені В. Долгочуб і Н. Петрова [2] виявили, що позаакадемічна діяльність не має жодного стосунку ні до академічної, ні до професійної академічної освіти. На їхню думку, кожний життєвий чи освітній факт потребує розгляду відповідно до його неоднорідності, незалежно від того, яскраво чи слабко виражені межі між структурними складовими частинами. Розглядаючи природу позаакадемічної науки, 3. Зайцева вбачає ії в «локалізації українського наукового простору, якому історично притаманна двоцентровість» [3, с. 29]. Ще на початку XX ст. заклади вищої освіти України прагнули автономії для панування ідеалу чистої науки, що могло створити об'єднання інтелектуального світу з політичним [3, с. 29].

Питання філософсько-практичного освоєння світу зацікавило дослідника Л. Мальцева, який розглядав репрезентативний напрям дослідження соціокультурної діяльності. Він зазначив, що «позаакадемічним проявом культури є масовість». На його думку, джерелами позаакадемічної діяльності $є$ натхнення, відтворене емоційно-чуттєвим світом людини та реально наявними відносинами між особистістю і навколишнім світом. «Здатність перетворення, руху, змін, протилежності начал, переходу з одного стану в інший є ознакою проникнення людини в основи буття» [4, с. 3].

Ще на початку XX ст. заклади вищої освіти України прагнули автономії для панування ідеалу чистої науки, що могло б створити об'єднання інтелектуального світу з політичним. Всесвітньо відомий експерт із питань освіти, англійський учений К. Робінсон наголошує на необхідності революційної зміни парадигми освіти з академічної на позаакадемічну. Причинами перебудови є «економічні і культурні зміни в суспільстві XXI ст., які розкривають інтелектуальний потенціал соціуму» [5]. Як наукову категорію поняття «позаакадемічна освіта» розглядає польський учений Б. Кшиш, формулюючи академічну і позаакадемічну види освіти як центральні взаємопов'язані світи науки. Він наголошує на необхідності піднесення в суспільстві і державі значення «позаакадемічної науки як мобільної і актуальної ланки освітньої системи» [6]. 
Мета статті - філософський аналіз відображення феномену позаакадемічної освіти в сучасному суспільстві.

Виклад основного матеріалу. Виклики суспільства привели до появи нової дефініції, розуміння сутності якої виокремлюється 3 поняття «освіта», що включає в себе академічний напрям і забезпечує надання освітніх послуг за освітньо-кваліфікаційними програмами відповідно до визначених законодавством рівнів, стандартів і кваліфікацій, визнаних державою. Отже, «позаакадемічною освітою» є ті види і форми освіти, які не увібрало в себе поняття «академічна освіта», тобто неформальна й інформальна, до яких входять позашкільна, надання часткових кваліфікацій, освітній процес на виробництві, на курсах, на семінарах чи самоосвіта за допомогою засобів масової інформації, спілкування, відвідування установ культури.

Доцільність дослідження новітньої освітньої системи набуває особливої значущості в сучасних соціокультурних умовах, коли наявне превалювання однобічного та спрощеного ставлення особистості до дійсності, що призводить до руйнування ідеальних суспільних норм. Потреба підвищення довіри до результатів освіти спричинила появу Методики оцінювання ефективності діяльності наукових установ НАН України, що була затверджена в березні 2017 р. В оцінюванні протягом 2017-2018 pр. брали участь експертні коміciї, третину з яких репрезентували «представники позаакадемічних установ» [7, с. 1], що показує високий рівень удосконалення професійної кваліфікації, здобутої в установах, які не належать до академічних.

У ст. 12 Закону України «Про освіту» профільна середня освіта передбачає академічне і професійне спрямування. До академічного належить профільне навчання на основі поєднання змісту профільної середньої освіти і поглибленого вивчення окремих предметів з урахуванням здібностей і освітніх потреб здобувачів освіти. Професійне визначається ж таким профільним навчанням, яке поєднує зміст профільної середньої освіти та професійно орієнтованого підходу до навчання з урахуванням здібностей і потреб учнів [8]. Тобто академічне навчання спрямоване на подальше підштовхування здобувача до академічної вищої освіти, а профільне є кінцевою освітою, яка передбачає працевлаштування і роботу за фахом після закінчення навчального закладу.

Державні, комунальні, приватні й інші заклади освіти як центри позашкільної освіти діють у системі позашкільної освіти, як визначає Закон України «Про позашкільну освіту». Також вона зумовлюється закладами, де надається не академічна освіта, ідеться про гуртки, секції, клуби, культурно-освітні, спортивно-оздоровчі, науково-пошукові установи на базі загальної середньої освіти, виробничих комбінатів та інших закладів освіти [9]. Шкільна освіта забезпечує академічну загальну середню освіту. Тобто, відповідно до нашого дослідження, деякі прототипи позашкільної освіти можна назвати позаакадемічними.

Професійно-технічна освіта, відповідно до Закону України «Про професійно-технічну освіту», є складовою частиною системи освіти України. Це заходи, спрямовані на оволодіння громадянами знаннями, уміннями і навичками в обраній ними галузі професійної діяльності, розвиток професійної компетентності і формування загальної і професійної культури. У ст. 4 визначено, що в цій системі діють професійно-технічні навчальні заклади будь-якої форми власності, що здійснюють підготовку кваліфікованих робітників [10].

Позаакадемічна освіта посіла особливе місце в розвитку особистості, перевіряючи часом основні постулати освіти. У 1996 р. укладена міжнародна угода «Міжнародна програма роботи в області освіти, інформування громадськості й підготовки кадрів» щодо необхідності змін у базових основах роботи традиційних освітніх закладів. Із спрямувань 
діяльності позаакадемічної освіти можна почерпнути підходи, які забезпечили переваги та швидку переорієнтацію напрямів роботи цієї форми освіти відповідно до запитів ринку праці [11].

Нині на сайті законодавства Свропейського Союзу можна знайти документи, що стосуються основ упровадження позаакадемічної освіти. Резолюція про значення позаакадемічної освіти в рамках європейської молодіжної сфери підкреслює ії̈ важливість у новій парадигмі навчання для логічно-праксеологічного відображення освітніх потреб особистості [12].

Уряд України у 2017 р. представив Національну доповідь «Цілі сталого розвитку 2016-2030», згідно з якою академічна і позаакадемічна освіта в аспекті нашого дослідження $є$ магістральним модусом інтелектуального потенціалу нації. Провідною думкою позаакадемічної освіти є перетворення наявної парадигми за допомогою необхідних змін змістовних і методичних параметрів форм освіти [13].

8 травня 2018 р. Міністерство науки і освіти України видало наказ «Про створення робочої групи з розроблення Стратегії інноваційного розвитку України». У проєкті «Стратегії інноваційного розвитку України на 2010-2020 pр. в умовах глобалізаційних викликів» наголошено на тому, що освіта $є$ однією з конструктивних ланок взаємопов'язаної системи «наука - освіта - виробництво». Як зазначено в документі, «освітній потенціал забезпечує $<\ldots>$ професійними навичками майбутніх працівників, знаннями населення на основі прогресивного досвіду інновацій, інформаційних технологій, культурного розвитку, соціально-економічних досягнень» [14].

Порівнюючи молоде покоління, яке здобуває вищу чи професійну освіту, та здобувачів освіти протягом життя, можна сказати, що позаакадемічна освіта може врятувати суспільство, відзначивши своє місце у трьох парадигмальних видах освіти - просвітницькій, індустріальній та постіндустріальній. «Парадигма постіндустріальної освіти має перспективи інноваційності та позаакадемічності» [15].

Академічна освіта по своїй суті невід'ємно залежить від держави, яка не завжди має ресурси підтримати свого навчального послідовника. Це перетворюється на негативне бачення вітчизняної науки на світовій освітній арені. Освіта є «підсистемою суспільства, вона залежна від конкретних реалій суспільства, яке, у свою чергу, перебуває в контексті сучасної цивілізації й на макрорівні має визначатись у своєму подальшому цивілізаційному поступі» [16, с. 437].

Фахівці, випускники навчальних закладів, академічних чи позаакадемічних, мають володіти професійно значущими здібностями, що збігаються зі змістом затребуваних суспільством нових ролей і функцій для забезпечення достатнього рівня добробуту населення. Глобалізаційні процеси, що відбуваються у світовій економіці, зумовлюють їх трансформацію, чинниками якої виступають об'єктивні освітні, науково-технологічні, соціальні, політичні, культурні процеси тощо.

Не применшуючи значення академічної освіти, можна сказати, що позаакадемічна освіта побудована навколо студента, не зациклена на тестах і контрольних, використовує посилення ролі зворотного зв'язку та співпраці викладача і студента. Проблема співвідношення академічної і позаакадемічної освіти загострилась у зв'язку з розвитком технічного прогресу, глобалізації. Позаакадемічна освіта стала затребуваною в усіх сферах діяльності людини, що привело до об'єднання фундаментальних ідей у освіті, основою яких є індивідуальність, унікальність і професіоналізм, спрямовані на розвиток світової глобальної освіти.

I. Вановська визначає формальну освіту як освіту, що реалізується відповідно до державних стандартів і забезпечує отримання документа про отримання якоїсь кваліфі- 
кації чи професії державного зразка, тобто вона є академічною. Формальна освіта надається у спеціальних установах і організаціях, офіційні програми яких розробляє держава. Неформальну освіту вчена встановлює як навчання поза закладами формальної освіти, яке забезпечує здобуття знань, умінь і навичок, що доповнюють формальні. Ця навчальна робота, як і формальна, має мету і часові рамки, але по закінченню не видається диплом державного зразка. «Інформальна освіта виконує функцію навчання впродовж життя поза навчальними закладами, коли повсякденний досвід впливає позитивно на знання особистості» [17, с. 27].

Філософський аналіз освіти в усі часи розглядається як відображення соціально-культурних процесів у суспільстві, що мають як приватний характер, так і глобальний світовий масштаб. Потреба у формуванні нової філософської концепції освіти особливо актуальна в умовах сьогодення, коли освітньою спільнотою робляться спроби побудови єдиного освітнього поля в межах Болонського процесу. Ці зміни впливають на трансформацію системи освіти, формування системи безперервної освіти. Складність вирішення означених проблем посилюється тим фактом, що є різні погляди й аксіологічні вимоги до системи освіти на всіх іï рівнях.

Висновки. Отже, можливості позаакадемічної освіти, які безпосередньо впливають на розвиток науки й особистості в контексті побудови власної траєкторії, можна визначити як актуалізацію побудови наявних прикладних областей знань і організацію доступу до суспільних проблем у практико-орієнтованому контексті, компетентнісний результат утворення інтелектуальної синергії та параметри функціональної навчально-освітньої діяльності. Позаакадемічна освіта стверджується в експлікації й екстраполяції прогресивних напрямів освіти, тобто організація, зміст і формалізація освітнього процесу, синтез науки і освіти відображаються в позаакадемічному супроводі функціонального процесу освітньої ідеї.

Сучасна парадигма позаакадемічної освіти виступає як діяльнісна форма розвитку особистості та фахівця, що грунтується на засадах створення продуктивної, а не репродуктивної системи передачі й отримання знань з урахуванням усього розмаїття суб'єктивних і об’єктивних викликів сьогодення. Вона орієнтує на вивчення процесу освіти як системи функцій, неправильна реалізація однієї з яких може вплинути на систему освіти загалом. Змістовна характеристика позаакадемічної освіти в широкому сенсі є надскладною системою, яка перебуває в постійному розвитку і розглядається як форма буття людини у світі. Грунтуючись на цьому розумінні, позаакадемічна освіта розглядається як сукупний спосіб і продукт діяльності. Вона включає в себе не тільки едукацію, формування професійних умінь і навичок, але і феномени, що виходять за рамки традиційних видів і форм освіти, як-от сумісне використання навчання і практики, формування відносин, які будуть потрібні в роботі, та ін.

\section{Список використаної літератури}

1. Волковський В. Ідея суспільності: політична філософія в Україні ХІХ ст. НАН України, Інститут філософії ім. Г.С. Сковороди. Київ : Академперіодика, 2017. 264 с.

2. Долгочуб В., Петрова Н. Прояви локальності в позаакадемічній реконструкції української традиційної культури. Народна творчість та етнологія. 2016. № 5. С. 18-22.

3. Зайцева 3. Інституціоналізація української науки наприкінці XIX - на початку XX ст. : автореф. дис. ... докт. істор. наук: 07.00.01. Київ, 2007. 40 с.

4. Мальцев Л. Молодіжна культура як предмет філософсько-естетичного аналізу : автореф. дис. ... канд. філософ. наук: 09.00.04. Київ, 1995. 23 с.

5. Ken R. Changing Education Paradigms. Speech, 2008. URL: http://www.cfpscourseweb. com/pluginfile.php/1099/block_html/content/RSA\%20\%20Ken\%20Robinson $\% 20$ Lecture\%20-\%20transcript.pdf (дата звернення: 22.08.2019). 
6. Krzych B. Gdy nauka staje się grą... (De) konstruktywnie i krótko o pewnych regułach świata akademii. Ur journal of humanities and social sciences. 2017. № 2 (3). P. 133-145.

7. Методика оцінювання ефективності діяльності наукових установ Національної академії наук України. URL: http://www.nas.gov.ua/text/pdfNews/metodyka_text.pdf (дата звернення: 26.08.2019).

8. Про освіту : Закон України від 5 вересня 2017 р. № 2145-VIII. URL: http://zakon3.rada. gov.ua/laws/show/2145-19/page (дата звернення: 16.10.2019).

9. Про позашкільну освіту : Закон України від 22 червня 2000 p. № 1841-III. URL: http:// zakon3.rada.gov.ua/laws/show/1841-14/page (дата звернення: 11.09.2019).

10. Про професійно-технічну освіту : Закон України від 10 лютого 1998 р. № 103/98-ВР. URL: http://zakon0.rada.gov.ua/laws/show/103/98-вp/page (дата звернення: 27.08.2019).

11. La"rhut - The global school and the national network of teacher educators for ESD in Sweden / K. Sonesson et al. Conference paper presented at creative learning for a sustainable world, Ljubljana, Slovenia, October 1-3, 2009. $6^{\text {th }}$ International Conference on Education for Sustainable Development and Creativity and Innovation.

12. Official website of the European Union. URL: https://europa.eu/european-union/index_ent (дата звернення: 03.09.2019).

13. Цілі сталого розвитку 2016-2030 : національна доповідь. URL: http:/www.un.org.ua/ ua/tsili-rozvytku-tysiacholittia/tsili-staloho-rozvytku (дата звернення: 05.10.2019).

14. Стратегії інноваційного розвитку України на 2010-2020 рр. в умовах глобалізаційних викликів : проєкт. URL: http://search.ligazakon.ua/1_doc2.nsf/link1/DF46L00A.html (дата звернення: 22.08.2019).

15. Жижко Т. Університетська освіта в умовах глобалізаційних викликів сучасного світу. Гілея. Історичні науки. Філософські науки. Політичні науки : науковий вісник : збірник наукових праць. Київ : ВІР УАН, 2010. Вип. 40. С. 320-326.

16. Рябченко В. Вища школа України в загальноцивілізаційному контексті: соціально-філософський аналіз з позицій світоглядно-компетентнісного підходу : монографія. Київ : Фітосоціоцентр, 2015. 674 с.

17. Вановська I. Аналіз базових компетентностей в сфері неперервної освіти. Освіта впродовж життя: сочіальні запити, сучасні виклики та пріоритети в реалізації : матеріали Конференції, м. Київ, 22 березня 2018 р. С. 26-31.

\title{
THE PHENOMENON OF NON-ACACADEMIC EDUCATION IN THE MODERN SOCIETY
}

\author{
Galina Zhukova \\ National Pedagogical Dragomanov University \\ Turgenivska str., 8/14, 02000, Kyiv, Ukraine \\ e-mail: galinazh1299@gmail.com
}

\begin{abstract}
Consideration of lifelong education as a social institution determines the relevance of the integration approach, which involves the use of measures' set of for interdisciplinarity of modern scientific knowledge. The significance of the search for new contexts of education as a productive direction for the development of research defines extracurricular education as an activity paradigm that needs theoretical analysis and scientific substantiation. The dialectic of education and upbringing exists in education, as a contradiction of culture and civilization within society, which is openly expressed in the discrepancy of education and upbringing. This process in education is most levelled when it is absorbed or merged with the training of skills and abilities of the relevant profession. In the cultural dimension of education in times of crisis, there is also a distortion of the interaction between upbringing and education. Upbringing here should be reflected in the state policy of building the content of education, which should represent
\end{abstract}


the achievements of world and national cultures. The development of non-academic education is seen as a socio-cultural phenomenon reflecting the growing need of the individual to receive various educational services. This educational system has such features as: organization, systematic, professional orientation, continuity, relevance to the already existing knowledge acquired by a person outside the academic educational system. The basic principles of non-academic education, regarding research of national, foreign scientists and Ukrainian state programs are: orientation of training to meet the actual needs of its persons; links with practices that are manifested in the pursuit of life skills and preparation for active participation in society; the presence of mobile flexible programs, individual educational strategies aimed at expressing, accepting and respecting individual characteristics.

Key words: continuing education, professional education, non-academic education, education system. 